\title{
Change of Selected Parameters of Steel Surface after Plasma Nitriding
}

\author{
David Dobrocky ${ }^{1}, Z_{\text {Zdenek Pokorny }}{ }^{1}$, Zbynek Studeny $^{1}$, Petr Dostal $^{2}$ \\ ${ }^{1}$ Department of Mechanical Engineering, Faculty of Military Technology, University of Defence in Brno, Kounicova 65 , \\ Brno 612 00, Czech Republic. E-mail: david.dobrocky@unob.cz, zdenek.pokorny@unob.cz, zbynek.studeny@unob.cz \\ ${ }^{2}$ Department of Technology and Automobile Transport, Faculty of AgriSciences, Mendel University in Brno, Zemědělská \\ 1665/1, 61300 Brno, Czech Republic. E-mail: petr.dostal@mendelu.cz
}

This article deals with the evaluation of the change of selected $2 D$ structure parameters of the grinded surfaces before and after application of plasma nitridation. Changes in parameters were analyzed on $30 \mathrm{CrMoV9}$ steel samples which were ground to $\mathrm{Ra} \approx \mathbf{0 . 0 3}$ and then plasma nitrided in a standard nitriding atmosphere. An absolute method was used to evaluate the surfaces. Measurements were performed on a profilometer CLI 1000. The parameters comprehensively describing the surface structure were subjected by analyzes, namely the height, length, shape parameters and parameters of the material ratio. After plasma nitriding, almost all selected surface structure parameters have been increased. Higher values of the monitored parameters have an influence on the increase of friction and wear and negatively affect the running-up properties of nitrided components.

Keywords: Grinded surface, Structure, Roughness, Plasma nitridation, Microgeometry

\section{Introduction}

In order to assess the functional properties of exposed machined surfaces, it is necessary to obtain the most complete description of the surface microgeometry properties. Creating the microgeometry of the machined surface, achieving the prescribed surface roughness characteristics is one of the factors entering the optimization of the cutting conditions of a particular machining operation as mentioned by Gerstenmeyer et al. (2017) [1], Sedlák et al. (2017) [2] and Baksa et al. [3].

The surface structure after abrasive operations is affected in particular by the dimensions of the grinding grains, their shape and the distance between them, the cutting speed of the grinding wheel and the longitudinal feed. During the grinding a plastic deformation occurs, which has two causes and which affects the microgeometry of the surface as indicated by Bumbálek et al. (2010) [4]:

- the first cause consists in the growth of grinding forces due to increased grinding depth, longitudinal feed, component speed, etc. The type of ground material directly affects the degree of plastic deformation that occurs in the rectilinear structure of the surface layer, the formation of transverse steps and cracks on the surface. Surface roughness deteriorates in this case;

- the second cause of plastic deformation during grinding is the increase of the temperature in the cutting zone along with internal and external friction. The high temperature in the metal micro-volumes causes the development of plastic deformation and residual internal stresses. However, the reduction of surface roughness from the above cause cannot be positively assessed because it is usually associated with degradation of the surface quality (burning, structural changes, internal residual tensile stresses) which is mentioned in work of Dubovska et al. (2014) [5], Sedlák et al. (2015) [6] and Mrkvica et al. (2018) [7].

Generally, in abrasive finishing methods, final surface microgeometry is produced both by the micro-cutting process and by the plastic deformation process - smoothing, polishing, Das et al. (2016) [8] and Hronek et al. (2018) [9]. Depending on the conditions of finishing, either one of these processes may occur, or they may happen gradually both of them. During the micro- cutting the necessary working allowance is removed and the plastic deformation and smoothing of the irregularities occur during polishing. There is a flow of metal from the peaks into the valleys, which ensures a minimum roughness of the surface as indicated by Hecker et al. (2003) [10] and Sadílek at al. (2018) [11].

The machined material (its structural-mechanical properties) has a considerable influence on the height and the character of the roughness of the machined surface. More plastic and tougher materials, such as low carbon steel, are more prone to plastic deformation and give rough surfaces when machined.

Increasing demands on functional surfaces created by machining (higher hardness, wear resistance and fatigue failure resistant) lead to the use of chemical-thermal processing methods of the exposed parts. One of the progressive chemical-thermal processing technologies is plasma nitridation. Plasma nitridation, as a method utilizing nitrogen surface saturation in a plasma environment, results in the formation of a nitrided layer on the surface of the component as mentioned by Pokorný et al. (2016) [12]. This layer is formed mainly by the diffusion process, but also by sputtering, which leads to changes in surface structure. Experimental work, which focused on the evaluation of the change in the structure of the steel surface after plasma nitriding, has shown that this diffusion technology leads to deterioration of surface structure parameters as is evident from work of Klanica et al. (2014) [13]. 
Higher surface roughness values after application of plasma nitriding lead to a change in the behavioral conditions of components, friction and wear are increased and durability and reliability are reduced.

\section{Experimental part}

Tab. 1 Chemical composition of 30CrMoV9 steel

\begin{tabular}{|c|c|c|c|c|c|c|c|c|}
\hline $\mathrm{C}$ & $\mathrm{Mn}$ & $\mathrm{Si}$ & $\mathrm{Cr}$ & $\mathrm{Ni}$ & $\mathrm{Mo}$ & $\mathrm{V}$ & $\mathrm{Al}$ & $\mathrm{Cu}$ \\
\hline 0.298 & 0.677 & 0.253 & 2.348 & 0.158 & 0.139 & 0.103 & 0.031 & 0.116 \\
\hline
\end{tabular}

\subsection{Sample preparation}

In order to verify the change of selected surface structure parameters after plasma nitriding, circular crosssection samples of $\varnothing 40 \mathrm{~mm}$ and thickness of $10 \mathrm{~mm}$ were prepared. The samples were grinded with surface grinder BPH 300 at a rotational speed of $2400 \mathrm{rpm}$ and a table feed rate of $10 \mathrm{~m} / \mathrm{min}$ with a grinding wheel 98A46J9V40 (J hardness). Each sample was abraded at $0.3 \mathrm{~mm}$ each.

\subsection{Evaluation of chemical composition of analysed steel}

The chemical composition of the selected steel was analyzed on the Tasman Q4 optical emission spectrometer. The results of the chemical composition are shown in Table 1.

Tab. 2 Parameters of heat treatment and plasma nitriding

\begin{tabular}{|c|c|c|c|c|}
\hline \multirow{2}{*}{ Quenching } & \multirow{2}{*}{ Tempering } & Temp./duration & Pressure & $\mathrm{H}_{2}: \mathrm{N}_{2}$ \\
\cline { 3 - 5 } & & $500^{\circ} \mathrm{C} / 8 \mathrm{~h}$ & $280 \mathrm{~Pa}$ & $24: 81 \cdot \mathrm{h}^{-1}$ \\
\hline $850^{\circ} \mathrm{C} /$ oil & $600^{\circ} \mathrm{C} /$ air & &
\end{tabular}

\subsection{Measurement of selected surface structure para- meters}

Selected 2D surface structure parameters were measured using an absolute method using the Talysurf CLI 1000, in accordance with ČSN EN ISO 4288 and ČSN EN ISO 13565-2. Sampling length of roughness $1 r=0.25$ $\mathrm{mm}$, evaluation length $\mathrm{ln}=1.25 \mathrm{~mm}$. Evaluation of $2 \mathrm{D}$ parameters was performed using Talymap Platinum software.

\section{Results and discussion}

2D surface structure parameters were evaluated from 3 measurements. Table 3 shows a comparison of selected roughness parameters of the ground surface and surface after plasma nitriding. The following 2D surface structure parameters were evaluated:

a) Height parameters:

- $\mathrm{Ra}-$ Arithmetic Mean Deviation of the roughness profile,

- $\quad \mathrm{Rq}$ - Root-Mean-Square (RMS) Deviation of the roughness profile,

- $\mathrm{Rt}$ - Total Height of the roughness profile,

- $\quad \mathrm{Rz}$ - Maximum Height of the roughness profile,

- $\quad \mathrm{Rp}$ - Maximum Peak Height of the roughness profile,

- $\mathrm{Rv}$ - Maximum Valley Depth of the roughness profile,

- Rsk - Skewness of the roughness profile,
The samples thus prepared were heat-treated by quenching and tempering on the mean strength limit. After finishing, the samples were grinded on the Struers Labopol metallographic grinder while cooling with water. The grain size of the Hermes sandpaper was chosen from 80 to $600 \mu \mathrm{m}$, according to FEPA.

Plasma nitriding was performed in Rübig PN 60/60 device to a surface hardness of $\approx 860 \mathrm{HV} 0.05$ and a layer thickness of $\approx 0.15 \mathrm{~mm}$. Parameters of heat treatment and plasma nitridation are given in Table 2.
- $\mathrm{Rku}-$ Kurtosis of the roughness profile,

b) Length parameters:

- $\mathrm{RSm}$ - Mean Width of the roughness profile elements,

c) Shape parameters:

- $\quad \mathrm{Rdq}$ - Root-Mean-Square Slope of the roughness profile,

d) $\mathrm{Rk}$ parameters (ISO 13 565):

- $\quad$ Rpk - Reduced peak height,

- Rvk - Reduced valley depth,

- Mr1 - Upper Material Ratio,

- $\mathrm{Mr} 2$ - Lower Material Ratio.

Tab. 3 Comparison of selected $2 D$ surface texture parameters

\begin{tabular}{|c|c|c|c|}
\hline Parameter & Unit & $\begin{array}{l}\text { Grinded } \\
\text { surface }\end{array}$ & $\begin{array}{l}\text { Plasma nitrided } \\
\text { surface }\end{array}$ \\
\hline $\mathrm{Ra}$ & \multirow{6}{*}{$\mathrm{nm}$} & 31.3 & 76.9 \\
\hline $\mathrm{Rq}$ & & 39.5 & 93.7 \\
\hline $\mathrm{Rt}$ & & 230.0 & 444.0 \\
\hline $\mathrm{Rz}$ & & 193.0 & 423.0 \\
\hline $\mathrm{Rp}$ & & 85.8 & 222.0 \\
\hline $\mathrm{Rv}$ & & 107.0 & 200.0 \\
\hline Rsk & \multirow[b]{2}{*}{-} & -0.314 & 0.124 \\
\hline $\mathrm{Rku}$ & & 3.19 & 2.52 \\
\hline $\mathrm{RSm}$ & $\mathrm{mm}$ & 0.0211 & 0.0214 \\
\hline Rdq & $\circ$ & 0.812 & 1.81 \\
\hline Rpk & \multirow{2}{*}{$\mathrm{nm}$} & 32.9 & 94.2 \\
\hline Rvk & & 51.8 & 75.0 \\
\hline Mr1 & \multirow{2}{*}{$\%$} & 11.8 & 10.3 \\
\hline $\mathrm{Mr} 2$ & & 90.0 & 90.9 \\
\hline
\end{tabular}


The evaluation of microgeometry of grinded surface and surface after plasma nitriding revealed that almost all of the surface structure parameters were increased by the chosen diffusion technology. A comparison of the profiles of the grinded and the nitrided surface is shown in Fig. 1.
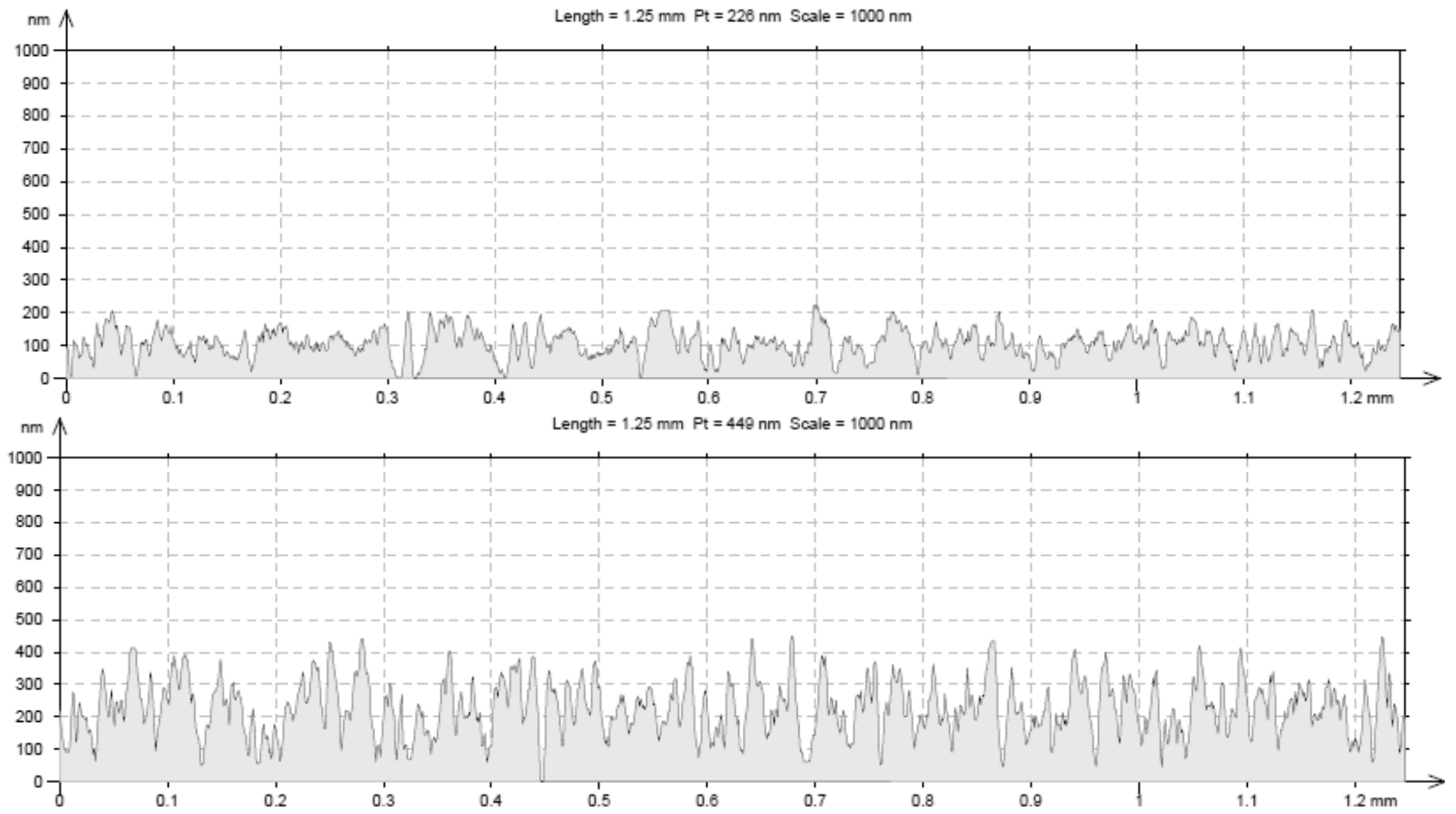

Fig. 1 Comparison of the profiles of the grinded (top) and nitrided surface (bottom)

\subsection{Height parameters}

In the case of height parameters (average values of the ordinates), the average arithmetic deviation $\mathrm{Ra}$ and the average quadratic deviation $\mathrm{Rq}$ of the profile under consideration increased by more than $100 \%$ (i.e. roughness deterioration). $\mathrm{Ra}$ is the industry's most widely used parameter, $\mathrm{Rq}$ is not much used in general engineering, although it is more important for statistical processing. The skewness value Rsk of the assessed profile increased several times, on the contrary, the kurtosis value Rku of the assessed profile decreased. Rsk indicates the character of the surface produced, the positive skewness characterizes the increase in friction as mentioned by Sedlaček et al. (2012) [14]. Decrease in Rku indicates a rougher appearance as indicated by Klanica et al. (2013) [15]. The Rku value of the grinded surface $(\mathrm{Rku}=3.19)$ characterises blunt peaks and a rough surface. Decrease of Rku after plasma nitridation indicates surface cleavage and sharp peaks. From this, it can be assumed the created nitrided layer to fill the surface of the grinded surface and creates sharper pointed peaks. Both of these parameters are, however, heavily influenced by sporadic peaks or valleys.

The height parameters evaluating the peaks and valleys also reached higher values in the case of the plasma nitrided surface. The maximum peak height of the roughness profile Rp has more than doubled, as did the increase of the maximum valley depth of the roughness profile $\mathrm{Rv}$, was by almost $100 \%$. Higher peaks lead to increased friction and wear, deeper valleys can lead to cracks propagation and corrosion. In correlation with the previous values, the maximum height of the roughness profile $\mathrm{Rz}$ (in the range of sampling length) has increased by more than twice. The total height of the roughness profile Rt (in the range of the evaluation length) increased by approximately $90 \%$, that is, the individual big peaks can increase the wear of the sliding surfaces. From the results, it can be concluded that during the process of plasma nitridation occur to faster increase of layer on created peaks of the profile, while the mechanism of the valleys filling has a lower speed.

\subsection{Length parameters}

From the length parameters, the mean width of the roughness profile elements RSm, which is determined by the arithmetic mean width of the profile elements in the sampling length range, was evaluated. The width of the elements in the case of the grinded surface is determined by the correlation between the spacing of the abrasive grains and their shape in the grinding tool, the grinding conditions (cutting speed, feed rate, etc.) and, last but not least, the chemical composition of the grinded material. After plasma nitriding, there was a small increase in the $\mathrm{RSm}$ value, which is due to the formation of a nitrided layer on the profile elements, which causes an increase in their width. RSm is often numerically equal to the grinder feed rate.

\subsection{Shape parameters}

The values of the root-mean-square slope of the roughness profile Rdq have increased by more than twofold. Increasing the angle of inclination of the inequality is a significant parameter because the greater slope of the angles of inequality is associated with higher wear of 
functional surfaces, lower surface resistance at its load and increase vibration during function of some components.

\subsection{Rk parameters (ISO 13 565)}

Rk parameters, or parameters of material ratio, affect the functional properties of the surfaces. The reduced peak height Rpk influences the run-in properties and has an effect on achieving the correct load between the functional surfaces. After plasma nitriding, the Rpk parameter increased by almost $200 \%$. Reduced valley depth of Rvk increased by about $50 \%$. Graphic representation of curves of linear material ratio is shown in Figure 2 and Figure 3.

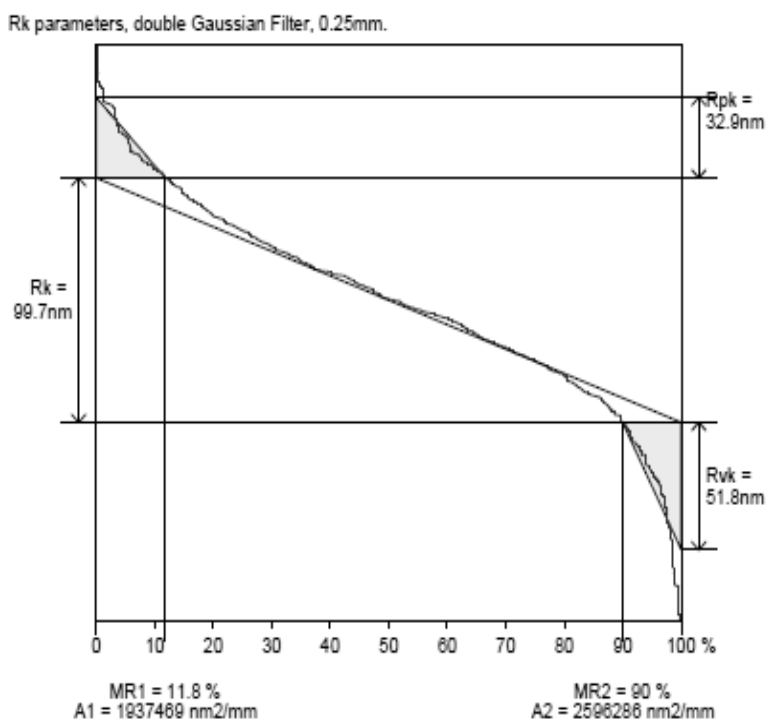

Fig. 2 The curve of the linear material ratio of grinded surface

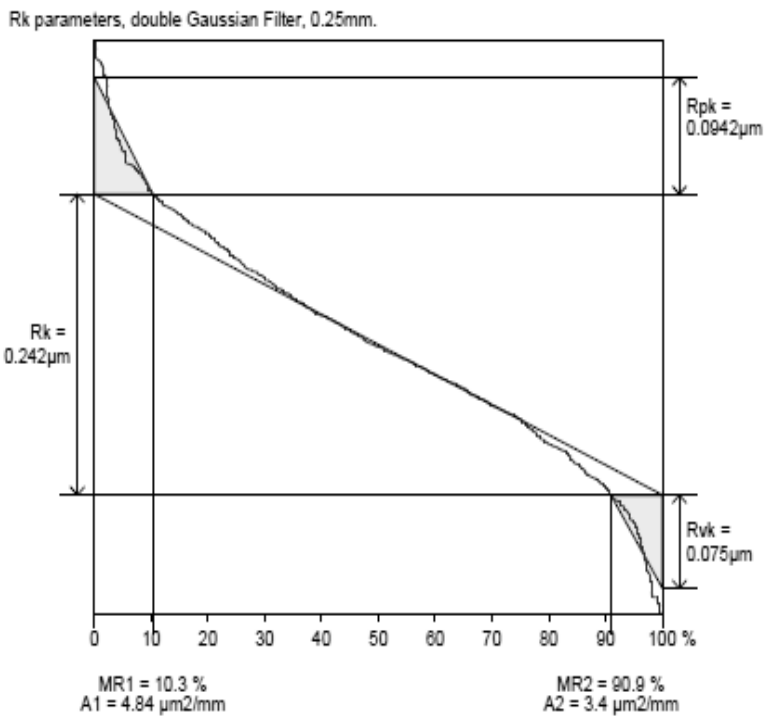

Fig. 3 The curve of the linear material ratio of nitrided surface

The curves of linear material ratio use like reimbursement of the general shape of the profile curve three straight lines. These three straight lines characterize three height parameters on the vertical axis and two characteristic points on the horizontal axis of the graph. Standard
ČSN EN ISO 13565-2 sets out the procedure for obtaining numerical values of individual characteristics (Rpk, Rk, Rvk, Mr1 and Mr2). This method of describing the curve of linear material ratio well describes the functional properties of the machined surfaces. Parameters Rk and Rpk are sensitive to profile shape changes that are particularly noticeable during the process of running-in, burnishing, etc., Tykal (1991) [16].

Result from the comparison of the material ratios relative to the peaks $\mathrm{Mr} 1$ and the valleys Mr2 there was a slight decrease of the value Mr1 (upper surface) and a slight increase of the value Mr2 (valleys) after plasma nitriding. The Mr1 parameter specifies the run-in properties, and the Mr2 parameter specifies the surface lubrication properties.

\section{Conclusion}

The experimental results on the samples made from $30 \mathrm{CrMoV} 9$ steel confirmed the change in the selected surface roughness parameters after plasma nitriding process. The chosen diffusion technology has led to an increase in almost all the measured surface structure parameters, in some cases up to $200 \%$. The increase in the evaluated parameters leads to the conclusion that the formed nitrided layer causes increased friction and wear, which, however, is contrary to the general theory and the practice of nitriding. Plasma nitriding is used in applications with increased wear. The coefficient of friction in case of nitrided layers increases but with a rise in temperature, it is markedly reduced compared with the grinded surface as mentioned by Doan et al. (2017) [17] and Kuilenburg et al. (2012) [18]. The change of the surface profile after plasma nitridation, which has been manifested by the increase of the valleys values, can lead to the development of cracks and corrosion, which is again contrary to the theory and practice of plasma nitriding as indicated by Kusmič et al. (2017) [19] and Kusmič et al. (2018) [20]. In this case, however, the stress states in the nitrided layer and its hardness are not taken into account. It should also be noted that the properties of the nitrided layer have been investigated only from the point of view of surface topography, not in terms of parameters of sliding properties and corrosion resistance parameters.

In terms of microgeometry, nitriding increases the width of peaks, magnifies the slope of peaks, and preferentially generates the nitrided layer at the vertices of the peaks than in the valleys.

The results of the material ratio parameters confirmed the above conclusions. The nitrided layer negatively affects the run-in properties, but it has a positive influence on the surface lubrication properties.

\section{Acknowledgement}

The paper was prepared with the support of the Project for the Development of the Organization „DZRO $K 201$ " and by the Specific research project 2016 of the Department of Mechanical Engineering ,SV16-216“. The research has been supported by the project TP 6/2017: Defectoscopic quality assessment of technical and organic materials; financed by $I G A$ AF MENDELU. 


\section{References}

[1] GERSTENMEYER, M., ORT, B.-L., ZANGER, F., SCHULZE, V. (2017). Influence of the Cutting Edge Microgeometry on the Surface Integrity During Mechanical Surface Modification by Complementary Machining, In: Procedia CIRP, Vol. 58, 2017, p. 55-60.

[2] SEDLÁK, J., POLZER, A., CHLADIL, J., SLANÝ, M., JAROŠ, A. (2017). Shape Inspection of Gear Prototypes Using Reverse Engineering Method. In: Manufacturing Technology, 2017, Vol. 17, No. 6, p. 945-952.

[3] BAKSA, T., SCHORNIK, V., ADAMEK, P., HRONEK, O., ZETEK, M. (2018). Effect of Grinding Conditions and Strategy on the Quality of the Cutting Edge, In: Manufacturing Technology, Vol. 18, 2018, No. 1, p. 3-7. ISSN 1213-2489.

[4] BUMBÁLEK, B., BUMBÁLEK, L. (2010). Surface texture after grinding of ceramic materials and its influence on the friction, In: International Journal of Computational Materials Sciences and Surface Engineering, Vol. 3, 2010, No. 1, p. 172183. ISSN 1753-3465.

[5] DUBOVSKA, R., JAMBOR, J., MAJERIK, J. (2014). Qualitative Aspects of Machined Surfaces of High Strength Steels, In: Procedia Engineering, Vol. 69, 2014, p. 646-654.

[6] SEDLÁK, J., TROPP, P., CHLADIL, J., OSIČKA, K., SLIWKOVÁ, P. (2015). HighSpeed Cutting of Bearing Rings from Material 100Cr6. In: Manufacturing Technology, Vol. 15, No. 5, p. 899-908.

[7] MRKVICA, I., ŠPALEK, F., SZOTKOWSKI, T. (2018). Influence of Cutting Tool Wear when Milling Inconel 718 on Resulting Roughness. In: Manufacturing Technology, Vol. 18, 2018, No. 3, p. 457-461. ISSN 1213-2489.

[8] DAS, J., LINKE, B. (2016). Effect of Manual Grinding Operations on Surface Integrity, In: Procedia CIRP, Vol. 45, 2016, p. 95-98.

[9] HRONEK, O., ZETEK, M., BAKSA, T., ADAMEK, P. (2018). Surface Quality Analysis of Cutting Tool Microgeometry to Achieve Higher Durability. In: Manufacturing Technology, Vol. 18, 2018, No. 1, p. 39-46. ISSN 1213-2489.

[10] HECKER, L.R., LIANG, S.Y. (2003). Predictive modelling of surface roughness in grinding, In: International Journal of Machine Tools and Manufacture, Vol. 43, 2003, No. 8, p. 755-761.

[11] SADÍLEK, M., KOUSAL, L., NÁPRSTKOVÁ, N., SZOTKOWSKI, T., HAJNYŠ, J. (2018). The
Analysis of Accuracy of Machined Surfaces and Surfaces Roughness after 3axis and 5axis Milling. In: Manufacturing Technology, Vol. 18, 2018, No. 6, p. 1015-1022. ISSN 1213-2489.

[12] POKORNÝ, Z., HRUBÝ, V., STUDENÝ, Z. (2016). Effect of nitrogen on surface morphology of layers, In: Metallic materials, Vol. 54, 2016, No. 2, p. 119-124. ISSN 1338-4252.

[13] KLANICA, O., DOBROCKÝ, D., ONDERKA, F. (2014). The changes of surface parameters of the duplex systems: nitrided layer - coating at CoCrMo alloy, In: ECS Transaction 15th Abaf Brno 2014 Advanced Batteries, Accumulators and Fuel Cells, 2014, p. 255-259. ISSN 1938-5862.

[14] SEDLAČEK, M., PODGORNIK, B., VIŽINTIN, J. (2012). Correlation between standard roughness parameters skewness and kurtosis and tribological behaviour of contact surface, In: Tribology International, Vol. 48, 2012, p. 102-112.

[15] KLANICA, O., SVOBODA, E., SONDOR, J., BARTOŠÍK, P., HRUBÝ, V. (2013). Změna textury povrchu povlaků na nástrojích po leštění, In: Vrstvy a povlaky, 2013, p. 145-150. ISBN 978-80970824-2-0.

[16] TYKAL, M. (1991). Význam nosné křrivky profilu nerovností povrchu a její posuzování. In: Drsnost povrchu a její vlivy na funkci součástí, 1991, Brno, s. $90-96$.

[17] DOAN, T.V., KUSMIČ, D., POSPÍCHAL, M., TRAN, Q.D., NGUYEN, V.T. (2017). Friction and wear Behaviour of 42CrMo4 Steel Treated by Tenifer, Hard Chrome and Plasma Nitriding Technologies, In: Manufacturing Technology, Vol. 17, 2017, No. 2, p. 168-174. ISSN 1213-2489.

[18] KUILENBURG, J. V., MASEN, M.A., GROENENDIJK, M.N.W., BANA, V., HEIDE, E. V. D. (2012). An experimental study on the relation between surface texture and tactile friction, In: Tribology International, Vol. 48, 2012, p. 1521.

[19] KUSMIČ, D., DOAN, T.V. (2017). Tribological and corrosion properties of plasma nitrided and nitrocarburized 42CrMo4 steel, In: IOP Conference Series: Materials Science and Engineering (MSE), IOP Publishing Ltd., Bristol, England, 2017, p. 19. ISSN 1757-8981.

[20] KUSMIČ, D., DOAN, T.V., HRUBY, V. (2018). Corrosion and Wear Resistance of Plasma Nitrided and Duplex Treated 42CrMo4 Steel. In: Manufacturing Technology, Vol. 18, 2018, No. 2, p. 259-265. ISSN 1213-2489. 